\title{
BERNARDO BEIGUELMAN (1932-2010)
}

Bernardo Beiguelman, Emeritus Professor of the State University of Campinas (UNICAMP), was born in Santos, Brazil, on May 15th, 78 years ago. It was there where he went to school and initiated his first studies. After finishing high school he moved to São Paulo, where he obtained his bachelor degree in Natural History at the University of São Paulo (USP). After graduating he became a high school teacher, and at the same time, moved by his restless personality, started, almost as an autodidact a study on the Cerrado flora and soon introduced into his teaching activities examples taken from scientific work on the physiology of peculiar plants of this biome. This research on the physiology of certain plant species composing the Cerrado vegetation was the building block for his doctoral thesis and marked the start of a brilliant scientific career.

By the late fifties, he moved to Marilia, where he taught biology at the State School of Philosophy (Escola Estadual de Filosofia). After a short but successful period in Marilia he moved again, this time to Campinas, where he became a professor at the Medical School of UNICAMP, and from where he also retired as an Emeritus Professor.

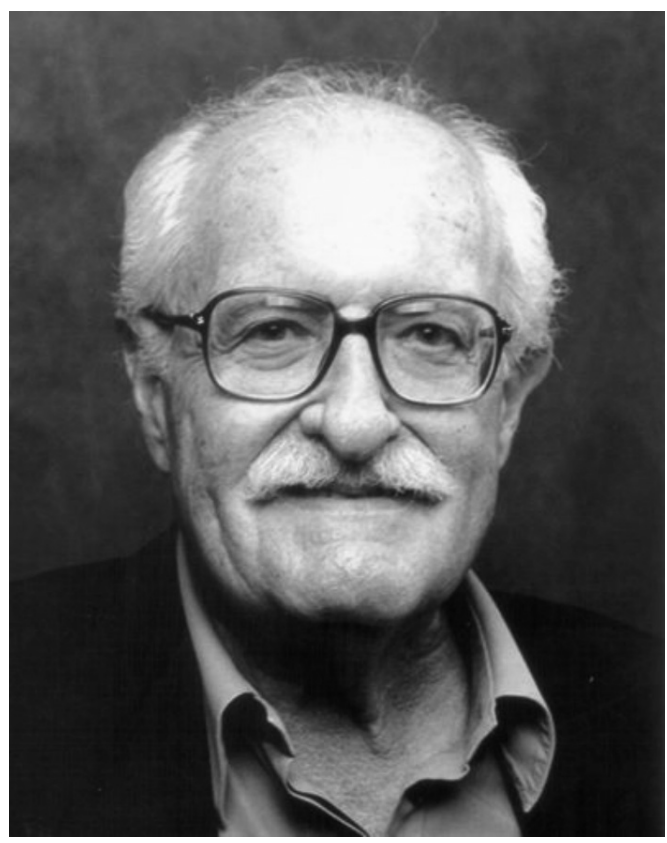

During his scientific career he was the author of more than 450 scientific contributions, including books, book chapters, original scientific articles and scientific communications at Congresses held both in Brazil and several foreign countries. He also gave countless invited conferences and seminar presentations at international and national meetings, as well as at foreign institutions.

His pioneering contributions to the understanding of the role of hereditary mechanisms in the susceptibility to leprosy are a landmark in scientific research, and so are his studies on the genetics and anthropology of twinning epidemiology. His contributions to science are highly admired and respected by the scientific community.

He was an adviser for the World Health Organization during 20 years and a member of the Brazilian Academy of Sciences and of the Academy of Sciences of the State of São Paulo. The Brazilian Government honored him with the highest award, The Order of Scientific Merit.

While this impressive list describes Bernardo Beiguelman's factual achievements in science and education, his friends and colleagues will also dearly remember him for his outstanding and warm personality. He was married for almost 50 years to his wife Silvia with whom he had four lovely children, Gisele, Evani, Lilian and the late Luciano. We also remember him as an expert violinist and guitar player, as a cinema devotee and lover of the fine arts. He also was a man dedicated to social problems and the improvement of life conditions in his country. His innovative logic and intelligence when discussing scientific matters, his honesty when arguing on how these should be applied in our country, and the superb humor and didactic skills which enriched his lectures, have deeply touched and inspired countless students and researchers. Brazil, his colleagues, friends and family will miss him.

$$
\begin{array}{r}
\text { Henrique Krieger } \\
\text { Departamento de Parasitologia } \\
\text { Instituto de Ciências Biomédicas } \\
\text { Universidade de São Paulo, São Paulo, SP } \\
\text { Walter Pinto Jr } \\
\text { Retired Professor } \\
\text { Departamento de Genética Médica } \\
\text { Faculdade de Ciências Médicas } \\
\text { Universidade Estadual de Campinas, Campinas, SP }
\end{array}
$$

